\title{
The Efficacy of Monetary Policy: A Tale from Two Decades
}

\author{
Daniel L. Thornton, Vice President and Economic Adviser
}

$\mathrm{T}$ he Federal Open Market Committee (FOMC) has used the federal funds rate as its policy instrument since the late 1980s in the belief that reducing interest rates increases the demand for goods and services (aggregate demand), which in turn, increases output and employment. A commonly used norm to evaluate the stance of monetary policy shows that monetary policy was relatively tight during the 2000s and relatively easy since. Despite marked difference in the stance of monetary policy over these two decades, there is little difference in the average rates of output growth, unemployment, or inflation.

A norm that is commonly used to evaluate the stance of monetary policy is the natural rate of interest-the interest rate that would prevail if the economy were in equilibrium. The nominal interest rate is composed of the real rate of interest, which is independent of the stance of monetary policy, and the expected rate of inflation, which is determined by monetary policy. The equilibrium real interest rate is not observable, but a commonly used estimate is 2 percent.

The FOMC made an effort to reduce the inflation rate beginning in the late 1970s. By late 1991 the inflation rate had fallen to under 3 percent and had stabilized considerably. By 1993 six central banks had adopted numerical inflation targets and it was widely believed that the FOMC had an implicit inflation objective in the range of 1 to 3 percent. The FOMC has recently removed the ambiguity by adopting a 2 percent long-run inflation objective. In any event, the natural nominal interest rate is frequently assumed to be 4 percent. ${ }^{1}$ The chart shows the FOMC's funds rate target relative to the natural rate since 1990; the vertical line denotes June 2001. The chart suggests that monetary policy was tight during most of the period from January 1990 through June 2001 and easy during most of the period since.

Given the marked difference in the stance of monetary policy over these two decades, one might expect to find a similar marked difference in economic performance. The top table shows the average growth rate of real GDP, the unemployment rate, and inflation over the past two decades. The first column presents the average of these variables for the entire period, the second removes months or quarters of recession, and the third removes the effect of the financial crisis from the second period by ending the period in June 2007. Output growth was twice as high during the period when monetary policy was tight than when it was easy. Some of this difference is due to the fact that the

2007-09 recession was more severe and protracted than the 1990-91 and 2001 recessions. When the recessions are accounted for, the difference is much smaller. The difference is not improved, however, if the period of the financial crisis is removed. The unemployment rate is higher during the easy policy period; however, all of the difference can be attributed to the financial crisis and its aftermath. The average unemployment rates for 1990-2001 and 2001-07 are essentially the same. Absent recessions and the financial crisis the stance of monetary policy appears to have had essentially no effect on output growth or the unemployment rate.

More surprising is the fact that the marked difference in the stance of policy over the two decades had little effect on the average inflation rate of inflation. The average inflation rates were essentially the same whether the recession months were removed or second period ended in June 2007.

One possible explanation for these facts is policymakers were more concerned about inflation during the first decade and more concerned about output growth and the unemployment rate during the second. This possibility is investigated by regressing the difference between the FOMC's target and the natural rate $(p s)$ on the

\section{FOMC's Federal Funds Target, January 1990-March 2012}

Percent

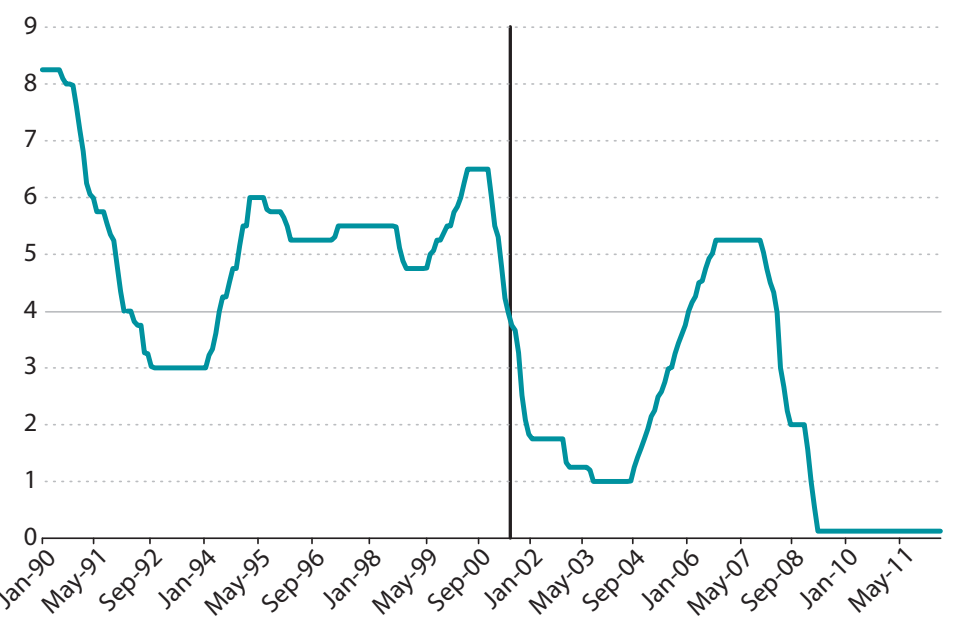

SOURCE: Federal Reserve Board/Haver Analytics. 


\section{Average Rates of Inflation, Output Growth, and Unemployment (\%)}

\begin{tabular}{lccc} 
Industry classification & Full sample & Without recessions & Without financial crisis \\
\hline January 1990-June 2001 & & & 2.30 \\
Headline PCE inflation & 2.40 & 3.70 & - \\
Growth rate of real GDP & 3.20 & 5.54 & - \\
Unemployment rate & 5.54 & 2.47 & 2.36 \\
July 2001-March 2012 & & 2.66 & 2.50 \\
Headline PCE inflation & 2.21 & 6.54 & 5.31 \\
Growth rate of real GDP & 1.65 & & \\
Unemployment rate & 6.50 & &
\end{tabular}

Estimates of the Equation $p s_{t}=\alpha+\beta u r_{t-1}+\delta p c e_{t-1}+\varepsilon_{t}$

January 1990-June 2001

\begin{tabular}{lccr}
\hline$\alpha$ & 1.222 & 0.953 & 0.807 \\
$\beta$ & -0.590 & - & -0.959 \\
$\delta$ & - & 0.564 & 1.024 \\
$\bar{R}^{2}$ & 0.258 & 0.170 & 0.736
\end{tabular}

July 2001-December 2008

$\begin{array}{ccc}-1.714 & -1.477 & -1.741 \\ -2.502 & - & -2.474 \\ - & 0.540^{*} & 0.069^{\dagger} \\ 0.846 & 0.073 & 0.845\end{array}$

NOTE: ${ }^{*}{ }^{\dagger} p$ values for these estimates are 0.045 and 0.573 , respectively; all other $p$ values are zero.

difference between the unemployment rate and 5.5 percent (ur) and on the difference between PCE inflation and 2 percent $(p c e){ }^{2}$ The equation was estimated over the periods January 1990-June 2001 and July $2001-$ December $2008 .^{3}$ The results are reported in the bottom table. ${ }^{4}$ The results for the first decade suggest that the FOMC was trying to stabilize both inflation and unemployment. Individually ur and pce are highly statistically significant, but account for only about 20 percent of the variation in the stance of policy: Jointly they explain about 75 percent of the variation in the stance of monetary policy, suggesting that the FOMC was attempting to stabilize both inflation and output during the period.

\section{Little difference in economic performance during the past two decades... is consistent with the theoretical and empirical evidence that monetary policy has no permanent effect on real variables.}

The estimates are strikingly different for the second decade: pce alone accounts for only 7 percent of the variation in the stance of policy, and the coefficient is marginally statistically significant at the 5 percent significance level. In contrast, $u r$ alone accounts for 85 percent of the change in the stance of policy. When both variables are included, pce is not statistically significant and there is no improvement in the equation's ability to explain the stance of policy.
These estimates suggest that the FOMC was concerned only with stabilizing output during the second period. The apparent focus on the real side of the economy is likely a consequence of inflation being effectively controlled by inflation expectations during the second period: With inflation anchored by inflation expectations, the FOMC was able to focus on the real variables.

The fact that there is little difference in economic performance during the past two decades despite a marked difference in the stance of monetary policy is consistent with the theoretical and empirical evidence that monetary policy has no permanent effect on real variables and with skepticism about the efficacy of the interest rate channel of monetary policy more generally. ${ }^{5}$ It also raises a question about the possible effectiveness of the FOMC's commitment to maintain the funds rate target at zero through late 2014 .

\footnotetext{
${ }^{1}$ Four percent is the figure John Taylor (1993) used in his famous Taylor rulea 2 percent real rate and a 2 percent inflation target-which is still commonly used in analyses of monetary policy using monthly and quarterly data.

25.5 percent is a frequently used estimate of the natural rate of unemployment.

3 The qualitative conclusions are the same if the equation is estimated over the period July 2001-March 2012; however, there is no variation in the dependent variable after December 2007. Also, the results are very similar if the independent variables are included contemporaneously, rather than lagged one month.

${ }^{4}$ The table presents the coefficient estimates with the corresponding significance level in parentheses below and the estimate of the adjusted R-squared, $\bar{R}^{2}$.

${ }^{5}$ For discussions of the limitations of the interest rate channel of monetary policy see Ben S. Bernanke and Mark Gertler, "Inside the Black Box: The Credit Channel of Monetary Policy Transmission." Journal of Economic Perspectives, 1995, 9(4), pp. 27-48, and Daniel L. Thornton, "How Did We Get to Inflation Targeting and Where Do We Need to Go to Now? A Perspective from the U.S. Experience," Federal Reserve Bank of St. Louis Review, January/February 2012, 94(1), pp. 65-82.
} 